\title{
Performance Difference Of Paud Teachers Certified With Non-Certified Teachers At Paud Institution In Kecamatan Medan Tembung T.A 2014/2015
}

\author{
Aman Simaremare ${ }^{a}$, Adiyani Shintarini \\ a Program Studi Manajemen Pendidikan, Universitas PGRI Semarang \\ Semarang, Indonesia
}

\begin{abstract}
This study aims to determine: the performance of certified teachers, non-certified teachers' performance, and differences in performance of certified teachers with non-certified teachers. This research is a comparative descriptive research. The target population of this study is the total of TK / PAUD teachers in Kecamatan Medan Tembung, whichamounted to 67 teachers. The sample stamps were taken on the basis of purposive sampling considerations with all certified teachers as many as 16 non-certified teachers and 16 teachers. Techniqueof datacollecting done by observation by using instrument of teacher performance appraisal. Research data were analyzed by using descriptive statistics to explain the performance condition of certified teachers and non-certified teachers, whereas to test the hypothesis of research is done inferential statistic by using $t$ test at $\alpha=0,05$. Based on the results of data analysis it is known that the average performance of certified teachers tend to be high, while the performance of non-certified teachers tend to be low. Furthermore, the results of hypothesis testing show: there is a significant difference between the performance of certified teachers with non-certified teachers where $t$ arithmetic $=2.433$ greater than $t$ table 1.697 at $\alpha=0.05$. Thus it can be concluded that the provision of teacher certification significantly influence the performance of teachers in TK / PAUD in Kecamatan Medan Tembung. This means that certified teachers perform better than non-certified teachers' performance.
\end{abstract}

Keywords: performance, teacher, certification, PAUD institution

\section{INTRODUCTION}

Early Childhood Education Institution is an institution that serves to conduct guidance addressed to children from birth up to the age of six years which is done through the provision of educational stimuli with a view to assist the growth and development of physical and spiritual children so that they have readiness in entering further education. These early childhood institutions are: Kindergarten (TK), RaudatulAtfal (RA), Playing Group (KB), Child Care Park (TPA) and PAUD. In achieving the goals of early childhood education, professional teachers who have educator certificates are required, as mandated in the Teacher Law and No. Law No. 14 of 2005 article 8 [1] stipulates that "teachers and lecturers shall have academic qualifications, competencies, educator certificates, physical and mental health, and meet other qualifications required by the higher education unit on duty, and have the ability to realize national educational goals". Another article is article 11, paragraph 1 states that the certification of educators as in article 8 is given to teachers who have met the requirements.

The figure of professional teachers in the learning process in schools including the PAUD institution occupies a very important position in achieving the educational goals of the institution. Although in this world of life advanced scientific and technological progress is growing rapidly, but the role of professional teachers remains the first and main in educating children toward the maturity expected by society. That is, the task and role of teachers can not be replaced by the sophistication of technology though, because the development of childhood personality in school can not be formed through technological sophistication, but formed through direct interaction that occurs between teachers with children as well as through the example of the teacher itself.

Educator certificates for early childhood teachers can be obtained through various certification programs through the path of portopolio, teacher training and professional education (PLPG), as well as teacher professional education (PPG). The demand for teachers certified by educators is not limited only to civil servant teachers but non-civil servant teachers who serve as teachers of kindergartens / early childhood in private also must have a certificate of educator. The certification program for teachers has been implemented since 2007, in the hope that certified teachers can perform better in addition to achieving better welfare 
compared to teachers who have not certified educators from teacher certification bodies in Indonesia. Through this certification program it is expected that teachers' performance in the learning process will be better if compared with teachers who have not certified.

The condition of teacher certified is currently the focus of the society stating that the performance of certified teachers with non-certified teachers' performance is equally unsatisfactory or low. Even non-certified teachers responding to the performance of certified teachers are no different from themselves as non-certified teachers resulting in apathy in the performance of their core tasks.Based on the above background, the formulation of this research problem are as follows: 1) How is the performance of certified teachers in PAUD institution in Kecamatan Medan Tembung ?, 2) How is the performance of non-certified teachers in PAUD institution in Kecamatan Medan Tembung ?, and 3) There is a significant difference between the performance of teacher certified teachers and noncertified teachers at PAUD institutions in Kecamatan Medan Tembung?

\subsection{Theoretical Framework}

\subsubsection{Teacher's Performance}

Etymologically Badudu formulate performance which means performance. In the English dictionary, performance is translated from the word performance which means the power to perform obligations or duties. Maier [2] gives performance limits as a person's success in performing a job. Lawler and Porter in As'ad [3] stated that job performance is a "succesful role achievement" obtainedSomeone of his deeds. As'ad [3] himself explained that job performance is the result achieved by a person according to the size applicable to the work in question. In line with that Build (2012) also states that performance is the result of work achieved by a person based on job standards (job standards). Mangkunegara in Arifin and Barnawi [4] defines performance as a result of work achieved by an employee either in quality or quantity in accordance with the responsibilities given to him. August W. Smith in Rusman (2011) states that performance is the output of derives of humanprocess or theirwise, meaning performance is the result of a human process. Then Wahyudi [5] gives understanding of performance in relation to the task of the teacher is as a result of work both in quality and quantity achieved by teachers in carrying out their duties in accordance with the responsibilities given to him. Saud [6] stated that teacher performance can be seen from his actual performance in planning teaching and learning process, implementing and managing teaching learning process, assessing progress of teaching and learning process, and mastering lesson material.

Other limits on performance are presented by Borman and Motowildo [7] who look at the performance of two aspects of performance in the context of a specific (job-specific behavior) and behavior (job non-specific behavior). Performance in the contextual sense is the result of work or output produced by a person related to the work done, while the performance in terms of behavior associated with the behavior that is displayed in a person's work such as cooperation, dedication (dedication), enthusiasm (enthusiasm), and Persistence. Then Coulquit, et al. [8] through an integrative model of organizational behavior defines performance not only as a result of final work that shows work performance but a set of behaviors shown by an employee or employee in carrying out his work. Behavior is meant to be seen from three dimensions of task performance (task performance), citizenship behaviors (citizenship behaviors), and counterproductive behaviors (counterproductive behaviors). The same view expressed Wibowo (2007) which explains the performance is not from the work alone but rather concerning the behavior of individuals in an effort to achieve the goals set.

Based on the above description, it can be synthesized that the performance of teachers is the work or achievement of work achieved by a teacher in carrying out his duties at school. The teacher's duties as set forth in the PAN and Bureau Reforms no. Chapter III article 6 point a and article 14 paragraph (2) items b and c., Which cover the main tasks in the process (the task of planning the lesson, carrying out the lesson, and assessing the lesson), the additional task of the relevant educator, and the development task Sustainable profession. However, in this study, teachers' performance is limited to the work or achievement of teachers in carrying out their main tasks in the school is the task of planning the lesson, implementing quality learning, assessing and evaluating learning outcomes.

The success of a person achieving the work performance in an organization is influenced by various factors. Accordingly, Blumberg and Pringle in Schermerhorn, Hunt, and Osbornt [9] describe the factors that influence individual performance through a model known as dimensions of individual performance factors: individual attributes, work effort, and organization support in which these three dimensions Interact with one another. Furthermore Gibson, Ivancevich\& Donnelly [9] suggests there are three variables that affect individual performance, namely: individual variables, organizational variables, and psychological 
variables. Lussier [11] pointed out that the level of performance achieved by employees is determined by three factors that are interdependent, namely: ability, motivation, and resources. While Arifin and Barnawi [4] more specifically suggested factors that affect teacher performance are salary, infrastructure, physical work environment, and school leadership. Meanwhile, Supardi [15] further highlighted the performance of its emphasis on the interaction between the basic ability factor (ability) and motivation (motivation) that exist in an individual.

From the opinions above can be explained in outline that the performance of an employee is influenced by factors derived from the individual self and factors that originate from outside the individual self. These factors include physical ability, mental ability, attitude, motivation, perception, salary, infrastructure, physical work environment, leadership, and so forth. Similarly with teachers, that the performance of a teacher is also influenced by various factors both derived from within the teacher itself such as the ability and motivation of work from the teacher itself or that comes from the teacher's work environment at school. One related to the certification that allegedly affects the performance of teachers is the salary as well as teacher certification allowance received from the government whose magnitude is generally greater than the salary received from the school's organizers each month. So the salary referred to in this study is the salary received by kindergarten teachers from the kindergarten school organizers and the receipt of additional salary in the form of teacher certification allowance from the government for teachers who have had the educator certificate in accordance with the prevailing laws and regulations.

\subsubsection{Teacher Certification}

Teacher certification is a process of recognizing a teacher by a certification through a competency test to reveal whether the teacher has competence to perform his or her service assignment in a particular educational unit. This is in accordance with the contents of the Law of RI No.14 of 2005 which states that the certification of teachers is a competency test process designed to reveal the mastery of one's competence as the foundation of the certificate of educators. Mulyasa [12] explains that teacher certification is a competency test process not intended for teachers in the office but also for prospective teachers who want to gain recognition of competence according to the profession he chose. Thus, this certification as a proof of recognition of the competence of teachers or prospective teachers who meet the standards to do the job of the teaching profession on certain types and levels of education.
Therefore, the certification process is seen as a partThe essence of obtaining competency certificates in accordance with established standards. Musclish [13] states that through certification teachers are expected to become competent professional educators as learning agents as evidenced by educator certificates. He further stated that the main objectives of teacher certification are to: 1) determine teacher's eligibility in performing tasks as a learning agent and realize national education goals; 2 ) improve the process and quality of educational outcomes; 3) improve teacher dignity; and 4) improve teacher professionalism.

While the benefits of the teacher certification program as set out in Government Regulation No. 19/2005 on National Education Standards include: 1) protecting the teachers' professions from incompetent practices, which could undermine the professional image of the teacher, 2) protect the community from uneducated educational practices Qualified and unprofessional, 3) the quality of education in schools is determined by the quality of teachers and the quality of the learning process in the classroom, and 4) improving teachers' welfare.

Based on the above explanation it seems clear that teachers who have educator certification must have a higher competency than teachers who do not have certification of educators in performing their professional duties as a learning agent in a particular educational unit. In addition it has been affirmed that the benefits felt by certified teachers is to improve teachers' welfare through the provision of one month basic salary certification allowance in accordance with the teacher's working class for teachers of civil servant status or the equivalent of civil servant teacher classroom for non-civil servant teachers.

Therefore, teachers who have had educator certificates and have received certification allowance for educators should really be able to demonstrate better performance of teachers who have not received educator certification allowance. This form of acceptance of teacher certification allowance must be visible from the performance of teachers in performing their professional duties, should appear to be more competent in terms of personality, social, pedagogical, and professional competence than teachers who have not received teacher certification allowance from the government because the process of obtaining certification It has been through special education and training by teacher certification institutions (government) so that teachers who are given educator certification and followed by providing educator certification allowance can realize the hope of government and society that is to improve the quality of national education. Thus, teachers who already have educator certificates are expected to be more professional in carrying out 
their main tasks in learning and better performance compared to non-certified teachers, there are differences in the performance of certified teachers with the performance of non-certified teachers in carrying out its main task in learning in school.

\section{RESEARCH METHODS}

The population of this study is the total of PAUD teachers in Kecamatan Medan Tembung T.A 2015, amounting to 67 teachers consisting of 16 certified teachers and 51 non-certified teachers spread to 18 PAUD schools. While the sample of this study are all certified teachers as much as 16 teachers and 16 non-certified teachers spread across 8 institutions of the same early childhood school. The dependent variable $(\mathrm{Y})$ of this research is teacher performance, while the independent variable (X) is certification and non certification. Data collection of research on teacher performance is obtained through observation technique by using teacher performance appraisal sheet by school supervisor of Kindergarten / early childhood. Further research data in descriptive analysis and to test the hypothesis used t test on $\alpha=$ 0.05 [14]

\section{DISCUSSION}

The results of data analysis descriptively show that the performance of certified teachers and performance of non certified teachers can be seen in the following table:

Table 1. Distributed Frequency of Teacher Certified Performance

\begin{tabular}{|l|c|c|c|}
\hline No. & Interval Class & Frequency & $\begin{array}{c}\text { Percent } \\
(\%)\end{array}$ \\
\hline 1. & $55-60$ & 3 & $\begin{array}{c}18.7 \\
5 \%\end{array}$ \\
\hline 2. & $61-65$ & 2 & $\begin{array}{c}12.5 \\
\%\end{array}$ \\
\hline 3. & $66-70$ & 4 & $\begin{array}{c}25 \\
\%\end{array}$ \\
\hline 4. & $71-75$ & 4 & $\begin{array}{c}25 \\
\%\end{array}$ \\
\hline 5. & $76-80$ & 3 & $\begin{array}{c}18.7 \\
\%\end{array}$ \\
\hline & Total & 16 & $\begin{array}{c}100 \\
\%\end{array}$ \\
\hline
\end{tabular}

From the table above it is known that the score of nikai certified teacher performance is more likely to be in the range of $66-70$ score and score $71-75$ with $25 \%$ each, followed by the range of score 55 60 and score $76-80$ with $18,75 \%$, while the other $12.5 \%$ is in the $61-65$ score range. Furthermore, the data trend test results show ideal ideal $(\mathrm{Mi})=67.5$ and ideal deviation standard (sdi) $=4.1$. Through the formula of the trend of data trends can be known level of teacher performance trends certified as presented in the following table;

Table. 2. Teachers Performance Trends

\begin{tabular}{|l|c|c|l|}
\hline Range & Frequency & Percentage & Category \\
\hline$\geq 71$ & $\mathbf{7}$ & $43.75 \%$ & Very High \\
\hline $65-70$ & $\mathbf{5}$ & $31.25 \%$ & High \\
\hline $45-64$ & $\mathbf{4}$ & $25 \%$ & Low \\
\hline$\leq 44$ & - & - & Very Low \\
\hline Total & $\mathbf{1 6}$ & $\mathbf{1 0 0} \%$ & \\
\hline
\end{tabular}

Based on table 2 above it can be seen that certified teacher performance level tends to high category with score range 65 - 70 equal to $31,25 \%$ and very high category with score range $\geq 71$ equal to $43,75 \%$. While the level of performance of certified teachers who belong to the category of low is only $25 \%$. To see more clearly the performance level of certified teachers is presented through the following chart graph; 


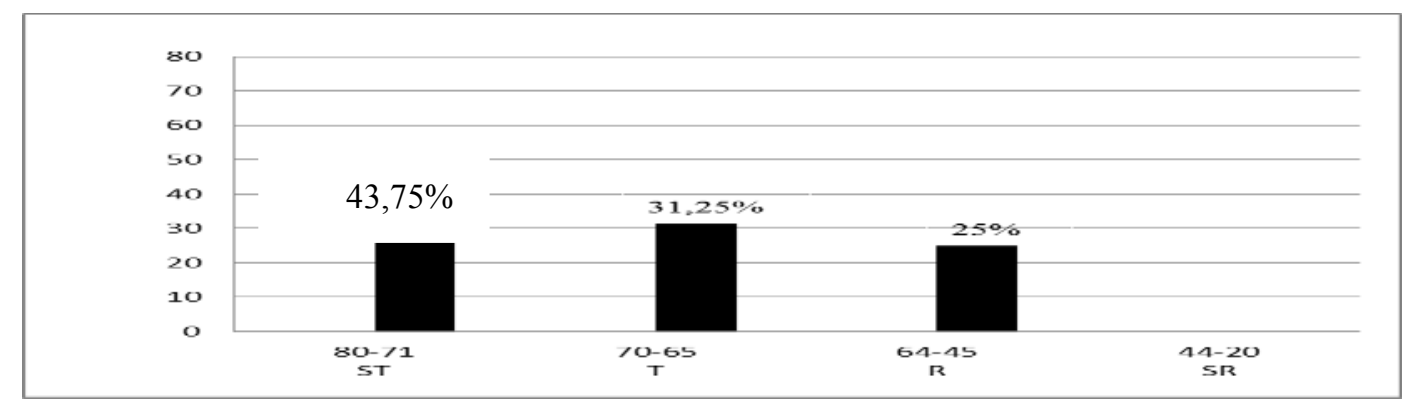

Figure 1. Stage chart of certified teacher performance level

Thus it can be concluded that the performance level of certified teachers is very high with a percentage of $43.75 \%$, while the level of performance of certified teachers who are low only $25 \%$. In other words, the performance of teacher certified teachers is very good at PAUD institutions in Kecamatan Medan Tembung.Furthermore the results of descriptive analysis of the performance of non-certified teachers at PAUD institutions in Kecamatan Medan Tembung are presented in the following table.

Table 3. Distribution of Frequency of Teacher Performance Non Certified (X)

\begin{tabular}{|l|c|c|c|}
\hline No & Interval Class & Frequency & Percentage \\
\hline 1. & $55-60$ & 3 & $18,75 \%$ \\
\hline 2. & $61-65$ & 8 & $50 \%$ \\
\hline 3. & $66-70$ & 4 & $25 \%$ \\
\hline 4. & $71-76$ & 1 & $6,25 \%$ \\
\hline & Total & 16 & $100 \%$ \\
\hline
\end{tabular}

From the table above, it is known that nikai score of non certified teacher performance is more likely to be in the range of 61-65 scores, which is $50 \%$ followed by 66 - 70 score ranges, $25 \%$ and 71 75 with $25 \%$ respectively, followed by range Score 55 - 60 equal to $18,75 \%$ and range of score $71-76$ that is equal to $6,25 \%$. Furthermore, the data trend test results show the ideal ideal $(\mathrm{Mi})=67.5$ and ideal deviation standard (sdi) $=4.1$. Through the formula of the trend of data trends can be seen the level of teacher performance trends non certified as presented in the following table:
Table 4. Teachers' Non-Certified Teacher Performance Trends

\begin{tabular}{|l|c|c|c|}
\hline Range & $\begin{array}{c}\text { Absolute } \\
\text { Frequency }\end{array}$ & $\begin{array}{c}\text { Relative } \\
\text { Percentange }\end{array}$ & Category \\
\hline$\geq 71$ & 1 & $6,25 \%$ & $\begin{array}{c}\text { Very } \\
\text { High }\end{array}$ \\
\hline $65-70$ & 5 & $31,25 \%$ & High \\
\hline $45-64$ & 10 & $62,5 \%$ & Low \\
\hline$\leq 44$ & - & - & $\begin{array}{l}\text { Very } \\
\text { Low }\end{array}$ \\
\hline Total & 16 & $100 \%$ & \\
\hline
\end{tabular}

Based on the figure 2 above can be concluded that the performance of non-certified teachers is low at $62.5 \%$, while the level of performance is high and very high only amounted to $37.5 \%$.Furthermore, the results of statistical calculations show $\mathrm{t}$ arithmetic $=$ 2.433 while $\mathrm{t}$ table $=1.697$ on $\alpha=0.05$ with $\mathrm{db}=32$ $-2=30$. Thus it is known that $\mathrm{t}$ arithmetic $>\mathrm{t}$ table $(2,433>1,697)$ conclusion shows there are significant differences regarding Performance of certified teachers with non-certified teachers at PAUD institutions in Kecamatan Medan Tembung.



Figure 2 Histogram Performance Level of Non Certified Teachers 


\section{DISCUSSION OF RESEARCH RESULTS}

The results of hypothesis testing have proved that there is a significant difference between the performance of certified teachers with non-certified teachers at PAUD Institution of Medan Tembung District. These results indicate that teacher certification influences teachers' performance in performing their main tasks in schools which in this regard are related to the task of planning the lesson, implementing the lesson, and assessing the learning. The result of this hypothesis test is supported by descriptive analysis result which shows that certified teacher performance tends to be high and very high that is $75 \%$ compared to non certified teacher performance which tend to low $62,5 \%$.

The performance of certified teachers is better than the performance of non certified teachers. It is understood that in order to obtain an educator's certificate for teachers has been through the process of education and professional training of teachers for 9 days (90 hours) organized by the teacher certification institution through college. During the certification program teachers are provided with a number of materials that support the implementation of its main duties at school, among others concerning government policy on teacher professional development, pedagogical materials, deepening of professional profession materials, teaching practice, and designing classroom action research in order to improve and improve the quality of learning in the classroom. The education and training of the teaching profession involves lecturers from universities of educational institutions and education personnel (LPTK) who act as instructors to facilitate teachers in realizing professional teacher competence such as pedagodic competence, professional competence, personality competence, and social competence. Thus the government's efforts in order to improve the quality and competence of teachers can be realized through the performance of teachers.

Better certified teachers 'performance compared to non certified teachers' performance can be understood as the impact of teacher professional education and training that equip participants to improve teacher competence required in the implementation of the educational process at a particular educational unit level. Another impact of teacher education and training is the increased welfare of teachers through the acceptance of teachers' professional allowance from the government in the form of money for one month of basic salary in accordance with the classroom teacher class for civil servant teachers or equivalent to the classroom for private teachers who work on
Schools organized by the community (foundation). Given this additional income teachers earn them more serious and have high motivation to work with the best so that can be realized in its performance better.

In relation to the results of this study indicating that there is a effect of certification on teacher performance where certified teachers show better performance than non-certified teachers in teachers at PAUD sub-district Medan Tembung, it can be stated that the high level of teacher performance can not be separated from financial factors such as salary Or certification allowances received by certified teachers. This is consistent with the statement of Barnawi (2012) that one of the factors affecting teacher performance is salary. The salary of teachers, including the acceptance of teacher certification allowance, constitutes the remuneration received by a teacher for his / her work from the administration of education / government in the form of financial periodically (every month) in accordance with applicable laws and regulations. The salary and teacher certification allowance received by certified teachers will also improve teachers' work motivation and strive continuously to improve their performance better. This is consistent with the statements of experts stating that a person's success achieves work or work performance in his or her work is influenced by various factors, one of which is the support of organizational factors such as resources (Blumberg and Pringle in Schermerhorn, 9; 11, rewards [9], or salary (Barnawi, 2012).

When the results of this study were correlated with preliminary studies suggesting that the performance of certified teachers with non-certified teachers in the view of the community as well as the views of teachers who have not certified are equally unsatisfactory, the results of this study indicate otherwise that the performance of certified teachers is better than that of teachers Non-certified at PAUD institution in Kecamatan Medan Tembung. This may be possible because the teacher performance aspect under study is still limited to the main tasks of the teacher in the lesson which includes the task of planning the lesson, the task of carrying out the lesson, and the task of doing the learning assessment.

To reveal the performance of teachers, especially for certified teachers, it is still necessary to conduct a more comprehensive research related to the main tasks of teachers as well as additional tasks and other supporting elements that describe the actual performance of teachers so that can really be revealed the impact of this certification on the performance of teachers in Achievement of national education goals. Is it true that the performance of 
certified teachers is better than teachers who are not certified. In addition, this teacher's performance can also be revealed through an assessment of student achievement.

\section{CONCLUSIONS SUGGESTIONS}

Based on the results of the research above, it is concluded that there is a significant difference between the performance of certified teachers and non-certified teachers at PAUD institutions in Kecamatan Medan Tembung. The performance of certified teachers is better than the performance of non-certified teachers at PAUD institutions in Kecamatan Medan Tembung. There is an effect of giving certification allowance from government to teacher performance at PAUD institution in Kecamatan Medan tembung.

Based on the results of the research above, it is concluded that there is a significant difference between the performance of certified teachers and non-certified teachers at PAUD institutions in Kecamatan Medan Tembung. The performance of certified teachers is better than the performance of non-certified teachers at PAUD institutions in Kecamatan Medan Tembung. There is an effect of giving certification from government to teacher performance at PAUD institution in Kecamatan Medan tembung.

\section{REFERENCES}

[1] Undang-undang Republik Indonesia Nomor 14 Tahun 2005 Tentang Guru dan Dosen.

[2] Maier, N.R.F. 1965, Psychology in Insdustry, 3rd.ed. , Boston: Hougton and Miffin.

[3] As'ad. 1987. Psikologi Industri. Edisi ketiga. Yogyakarta: Liberty.

[4] Arifin, Mohammad \&Barnawi. 2012. Kinerja Guru Profesional. Jogjakarta: Ar-Ruzz Media

[5] Wahyudi, Imam. 2012 MengejarProfesionalisme Guru. Jakarta:PrestasiPustaka.

[6] Saud, Udin Syaefudin.2011. Pengembangan Profesi Guru. Bandung: Alfabeta.

[7] Borman, W.C., and Motowidlo, S.J. 1993. Expanding the criterion domain to include elements of contextual performance dalam Handbook of Human Resources Managemen.

[8] Colquitt, Jason A., Lepine, Jeffery A. \& Wesson, Michael J. 2009. Organizational Behavior. New York: McGraw-Hill Companies, Inc.

[9] Schermerhorn, John R.Jr., Hunt, James G. \& Osborn,Richard N. $1985 . \quad$ Managing Organizational Behavior. 2/e. New York: John Wiley \& Sons.
[10] Gibson, James L., Ivancevich, John M. \& Donnelly, James H. 1985. Organizations. Behavior. Structure. Processes. 5/e. Texas: Business Publications, Inc.

[11] Lussier, Robert N. 2009, Managemet Fundamentals, Concepts, Applications, Skill Development, 4/e. , South-Western: Cengage Learning.

[12] Mulyasa. 2013. Uji Kompetensi dan Penilaian Kinerja Guru. Bandung: PT

[13] Muslich, Masnur. 2009. Sertifikasi Guru menuju Profesionalisme Pendidik. Jakarta: Bumi Aksara.

[14] Sugiono.2012. Metode Penelitian Bisnis. Bandung: Alfabeta.

[15] Supardi. 2014. Kinerja Guru. Jakarta: Rajawali Pers. 